\title{
A Study on Socio-economic Condition of Farmers Cultivating Makhana in Darbhanga District of Bihar, India
}

\author{
Ansar Ahmad ${ }^{1 *}$ and Birendra Kumar ${ }^{2}$ \\ ${ }^{1}$ Mohalla- Karamganj, Post- Laheriasarai, District - Darbhanga, Bihar-846001, India \\ ${ }^{2}$ Department of Agricultural Economics \& Statistics, Chandra Shekhar Azad University of \\ Agriculture and Technology, Nawabganj, Kanpur, India \\ *Corresponding author
}

\section{Keywords}

Farmers, Makhana, Bihar, Socioeconomic Condition

Article Info

Accepted:

08 January 2020

Available Online:

10February 2020

\section{A B S T R A C T}

In India, the cultivation of Makhana (Euryale ferox) is distributed in Bihar, West Bengal, Assam, Manipur, Tripura, Eastern Odisha, Madhya Pradesh, Rajasthan, and Eastern Uttar Pradesh. India is the only country where Makhana is cultivated as crop and mainly in the state of Bihar and some Parts of Assam. In Bihar, area under makhana cultivation is about 13,000 hectares and accounts to a total yield of 85 per cent of the total production in India. Major Makhana producing districts in Bihar include Darbhanga, Sitamarhi, Madhubani, Saharsa, Supaul, Araria, Kishanganj, Purnia and Katihar. It is a cash crop and is marketed in the form of popped makhana commonly known as Makhana Lawa. It is commonly known as Gorgon nut or Foxnut and grown in stagnant perennial water bodies like ponds, Oxbow lakes, and swamps. Cultivation of Makhana is highly cumbersome, labour intensive and involves human drudgery while sweeping bottom of the water body for seed collection. It is followed by processing of raw seeds, which is equally painstaking activity. Fishermen community (Mallah) belonging to the weaker sections of the society is mainly involved in makhana cultivation and processing. It is observed that, among the selected farmers 40 per cent were illiterate, 46 per cent were studied up to class Vth, 54 per cent respondents were in age group of above 50 years old, the farmers having family member of 6-10 people were 60 per cent, the farmers having annual income of Rs. 50,000 to $1,00,000$ was 32 per cent, the large number of people (62 per cent) were involved in other professions with agriculture and aquaculture for their livelihood. The farmers having 2 earner in the family was 56 per cent. And the farmers having up to 0.5 hecres of land was 68 per cent, the farmers taken pond on lease of up to 2 hectares was 82 per cent.

\section{Introduction}

Euryale ferox is an important aquatic crop, belonging to family Nympheaceae. It is commonly known as Makhana, Gorgon nut or Foxnut and grown in stagnant perennial water bodies like ponds, Oxbow lakes, and swamps.
Makhana cultivation provides livelihood to thousands of resource poor farmers, particularly in Bihar and Manipur. It is a cash crop and is marketed in the form of popped makhana commonly known as Makhana Lawa. In India, the cultivation of Makhana is distributed in Bihar, West Bengal, Assam, 
Manipur, Tripura, Eastern Odisha, Madhya Pradesh, Rajasthan, and Eastern Uttar Pradesh. India is the only country where Makhana is cultivated as crop and mainly in the state of Bihar and some Parts of Assam.

In Bihar, area under makhana cultivation is about 13,000 hectare and accounts to a total yield of 85 per cent of the total production in India. Major Makhana producing districts in Bihar include Darbhanga, Sitamarhi, Madhubani, Saharsa, Supaul, Araria, Kishanganj, Purnia and Katihar. Approximately, 80 per cent of the total production of processed Makhana comes from Darbangha, Madhubani, Purnia, and Katihar districts alone.

Cultivation of Makhana is highly cumbersome, labour intensive and involves human drudgery while sweeping bottom of the water body for seed collection. It is followed by processing of raw seeds, which is equally painstaking activity. Fishermen community (Mallah) belonging to the weaker sections of the society is mainly involved in makhana cultivation and processing. In traditional method is it is cultivated in ponds but now the cultivation has been started in the fields also. In field system it is cultivated in agriculture lands with one to two feet of water depth.

Makhana is an organic, nutritional, non-cereal edible crop. Makhana is a good source of carbohydrate, protein and minerals. In recent years price of makhana has increased due to increase in demand from domestic as well as foreign markets. The crop has been recognized as an important crop in the state of Bihar and has the potential to alleviate the poverty of section of people involved in its cultivation.

\section{Materials and Methods}

The present study was carried out in the
Darbhanga district of Bihar. The study aims at understanding the socio-economic condition of farmers cultivating Makhana (Euryale ferox). The brief description of methodological aspects used in the sampling techniques, collection of data and method of enquiry, period of enquiry, tools and techniques used in analysis are applied in attaining specific objective of study.

Purposive and random sampling techniques were used to select district, block, village, and farmers. The present study was conducted in Darbhanga district of Bihar. Darbhanga district was purposively selected for the study, as makhana has always been the major crop of the district and Darbhanga is famous for the production of makhana in Bihar and as well as in India. Among total of 18 blocks of district Darbhanga, three block which are major in the production of the makhana namely; Darbhanga Sadar, Manigachhi, and Keoty block. A list of all the three major makhana producing block was prepared and among the list one block Darbhanga Sadar was selected at random process. A list of all the villages practicing the makhana crop of the selected block was prepared and out of which 5 villages were selected randomly, namely devari, sonki, chuna bhatti, sara and mohanpur.

The selection of farmer was also based on the random process. The list of makhana cultivators of all the selected villages was prepared with the help of the Secretary of Fisherman cooperative society of the Block Darbhanga Sadar. Among them 10 cultivators/makhana growers were selected randomly from each village. Thus a total of 50 makhana growers were selected randomly from the universe of five selected village.

The primary data are collected from the farmers, in the study area through survey method and the pre-tested schedule are prepared specially for the purpose of the 
study. The collected data are cross checked with the head of the village, and is found to be authentic.

The tabular analysis was done by working out simple averages and percentages.

\section{Results and Discussion}

The present study is to ascertain the different socio-economic characteristics of the selected Makhana cultivators. The socio-economic characteristics of the farmers include; education, age, family size, annual income, source of income and number of earner in family. Analysis of socio-economic characteristics is required to have comprehensive view about the farmers and it may also be useful to the policy makers to formulate policies suitable to the farmers.

\section{Educational status}

The selected respondents were classified into five categories on the basis of the education attainment which are, illiterate, primary school, secondary school, intermediate school and graduation and above. It was observed from the table 1 that 20 respondents out of 50 were illiterate which constitute the 40 per cent of the total respondents. The number of farmers having education of primary school that is up to class Vth was 23 which constitute 46 per cent of the total respondents. The number of farmers having education up to secondary school that is from class Vth to class Xth was 6 which is 12 per cent of total number of respondents. And the number of famers who studied intermediate that is XIth and XIIth was 1 which is 2 per cent of the total respondents. There is no farmer who was graduate and above from the selected respondents, so the farmers who studied graduation and above was 0 per cent.

It was observed that the total percentage of illiterate and farmers studied up to primary school was 86 per cent. It was reported that the educational status of the farmers cultivating makhana is very poor.

\section{Age group}

On the basis obtained age the selected respondents were classified into five age group. The details of the age group and the results are shown in the table 2. It was observed from the table 5.2 that the farmer belonging to age group of 20-29 years old were 4 in number which is 8 per cent of total number of respondents, 9 farmers belong to the age group of 30-39 years old which was 18 per cent of the total respondents. In age group of 40-49 there were 10 farmers which is 20 per cent of total number of respondents, in age group of 50-59 there were 11 farmers which is 22 per cent and in the age group of above 60 there were 16 farmers which is 32 per cent of total number of respondents.

It is observed that the farmers above the age of 50 years were 54 per cent, and it shows that the youth are less interested in the cultivation of makhana.

\section{Family size}

The selected respondents were categorised into five groups that is $0-5$ members, 6-10 members, 11-15 members, 16-20 members and members more than 21 . It was observed from the table 3 that the farmers having family member up to 5 people were 2 which is 4 per cent, the farmers having family member of 6-10 people were 30 which is 60 per cent, the farmers having 11-15 members were 15 which is 30 per cent, the famers having family members $16-20$ peoples were 2 which is 4 per cent and the farmer having family member more than 21 people was only 1 which is 2 per cent of the total number of the respondents. 
It was observe that, the highest number of respondents having family member of 6-10 people and the percentage share was 60 per cent of total number of respondents. And the respondents having family member of 11-15 people are the second highest which was 30 per cent of the total number of the respondents. And it is also observed that there were 44 joint families and 6 nuclear family. It means that the 88 per cent of makhana growers are living in joint family and only 12 per cent are living in nuclear family.

\section{Annual income}

The selected respondents were categorised in various groups such as Rs.50,000 to 1,00,000, Rs. $1,00,001$ to $1,50,000$, Rs. $1,50,001$ to $2,00,000$, Rs. $2,00,001$ to $2,50,000$ and above $2,50,001$ according the their per annum income from makhana and other sources. The annual income of the respondents are shown in table 4. It was observed that number of respondents having annual income of Rs. 50,000 to $1,00,000$ was 16 , which is 32 per cent, the number of respondents having annual income of Rs. 1,00,001 to 1,50,000 was 6 , which is 12 per cent, the number of respondents having annual income of Rs. $1,50,001$ to $2,00,000$ was 8 , which is 16 per cent, the number of respondents having annual income of the Rs. 2,00,001 to 2,50,000 was 13 , which is 26 per cent and the number of respondents having annual income more than 2,500,000 is 7, which was 14 per cent of total respondents.

It was found that there was large variation in the incomes of famers and that is because of income from different sources. The respondents having income of Rs. 50,000 to Rs. 1,00,000 are the highest in number, there percentage share was 32 per cent in the total number of respondents. The respondents having income of Rs. 2,00,001 to Rs. 2,50,000 are second highest in number there percentage share in total number of respondents was 26 per cent.

\section{Source of income}

The source of income of the makhana cultivators are categorised into three groups such as; farmer performing agriculture only, famers performing agriculture and aquaculture and farmers performing agriculture, aquaculture and something other like labour work, jobs or business according to the data collected. In the table 5 it was observe that the number of farmers performing only agriculture was 2 which is 4 per cent, the number farmers performing agriculture and aquaculture was 17 which is 34 per cent and the number farmers performing agriculture, aquaculture and something other was 31 which is 62 per cent.

It is found that the highest numbers of farmer are involved in other works with agriculture and aquaculture for their livelihood, and the percentage share of the respondents in the total number of respondents was 62 per cent.

\section{Number of Earner in the family}

The number of earner in the family is categorised in three groups which are 1,2 and 3 according to the data collected of the sample farmers. In table 6 it was observed that the numbers of famers having only 1 earner in the family was 11 which is 22 per cent, the number of the farmers having 2 earner in the family was 28 in number which is 56 per cent and the number of the farmer which having 3 earner in the family was 11 in number which is 22 per cent of the total number of respondents. 
Table.1 Educational status of the sample farmers

\begin{tabular}{|c|c|c|c|}
\hline S.NO. & Educational Status & No. of Farmers & Percentage \\
\hline 1 & Illiterate & 20 & 40 \\
\hline 2 & Class Ist to Vth & 23 & 46 \\
\hline 3 & Class Vth to Xth & 6 & 12 \\
\hline 4 & Class XIth and Xth & 1 & 2 \\
\hline 5 & Graduation and above & 0 & 0 \\
\hline & Total no. of respondents & 50 & 100 \\
\hline
\end{tabular}

Table.2 Age group of the sample farmers

\begin{tabular}{|c|c|c|c|}
\hline S.NO. & Age group (years) & No. of farmers & Percentage \\
\hline 1 & $20-29$ & 4 & 8 \\
\hline 2 & $30-39$ & 9 & 18 \\
\hline 3 & $40-49$ & 10 & 20 \\
\hline 4 & $50-59$ & 11 & 22 \\
\hline 5 & Above 60 & 16 & 32 \\
\hline & Total no. of respondents & 50 & 100 \\
\hline
\end{tabular}

Table.3(a) Family size of the sample farmers

\begin{tabular}{|c|c|c|c|}
\hline S.NO. & $\begin{array}{c}\text { Family size (No. of } \\
\text { Members) }\end{array}$ & No. of farmers & Percentage \\
\hline 1 & $0-5$ & 2 & 4 \\
\hline 2 & $6-10$ & 30 & 60 \\
\hline 3 & $11-15$ & 15 & 30 \\
\hline 4 & $16-20$ & 2 & 4 \\
\hline 5 & Above 21 & 1 & 2 \\
\hline & Total no. of respondents & 50 & 100 \\
\hline
\end{tabular}


Table.3(b) Family type

\begin{tabular}{|c|c|c|c|}
\hline S.NO. & Family Type & No. of Farmers & Percentage \\
\hline 1 & Joint family & 44 & 88 \\
\hline 2 & Nuclear family & 6 & 12 \\
\hline & Total no. of respondents & 50 & 100 \\
\hline
\end{tabular}

Table.4 Annual Income of the sample farmers

\begin{tabular}{|c|c|c|c|}
\hline S.NO. & Income Group (Annual income) & No. of farmers & Percentage \\
\hline 1 & Rs.50,000 to Rs.1,00,000 & 16 & 32 \\
\hline 2 & Rs.1,00,001 to Rs.1,50,000 & 6 & 12 \\
\hline 3 & Rs.1,50,001 to Rs.2,00,000 & 8 & 16 \\
\hline 4 & Rs.2,00,001 to Rs.2,50,000 & 13 & 26 \\
\hline 5 & Above Rs.2,50,001 & 7 & 14 \\
\hline & Total no. of respondents & 50 & 100 \\
\hline
\end{tabular}

Table.5 Source of income of the sample farmers

\begin{tabular}{|c|c|c|c|}
\hline S.NO. & Source of Income & No. of farmers & Percentage \\
\hline 1 & Agriculture & 2 & 4 \\
\hline 2 & Agriculture + Aquaculture & 17 & 34 \\
\hline 3 & $\begin{array}{c}\text { Agriculture + Aquaculture + other (Job, } \\
\text { Business, Labour work) }\end{array}$ & 31 & 62 \\
\hline & Total no. of respondents & 50 & 100 \\
\hline
\end{tabular}

Table.6 Number of earners in the family of sample farmers

\begin{tabular}{|c|c|c|c|}
\hline S.NO. & Number of earners in family & No. of farmers & Percentage \\
\hline 1 & 1 & 11 & 22 \\
\hline 2 & 2 & 28 & 56 \\
\hline 3 & 3 & 11 & 22 \\
\hline & Total no. of respondents & 50 & 100 \\
\hline
\end{tabular}


Table.7 Owned land of the sample farmers

\begin{tabular}{|c|c|c|c|}
\hline S.NO. & Category of land & No. of farmers & Percentage \\
\hline 1 & Up to 0.5 hectares & 34 & 68 \\
\hline 2 & $0.5-01$ hectares & 15 & 30 \\
\hline 3 & $1-2$ hectares & 1 & 2 \\
\hline & Total no. of respondents & 50 & 100 \\
\hline
\end{tabular}

Table.8 Land taken on lease by sample farmers

\begin{tabular}{|c|c|c|c|}
\hline S.NO. & Leased land (acres) & No. of farmers & Percentage \\
\hline 1 & Up to 2 hectares & 41 & 82 \\
\hline 2 & 2 to 4 hectares & 8 & 16 \\
\hline 3 & 4 to 6 hectares & 0 & 0 \\
\hline 4 & 6 to 8 hectares & 0 & 0 \\
\hline 5 & Above 8 hectares & 1 & 2 \\
\hline & Total no. of respondents & 50 & 100 \\
\hline
\end{tabular}

\section{Owned land}

The area of land owned by the famers cultivating makhana are categorised in three groups which are up to 0.5 hectares, 0.5 to 1 hectares and 1 to 2 hectares. In the table 7 it was observed that the farmers having 0 to 0.5 hectares of land were 34 in numbers which is 68 per cent, the farmers having 0.5 to 1 hectares of the land were 15 in numbers which is 30 per cent and the farmer having 1 to 2 hectares of the land was only 1 in number which is 2 per cent of the total respondents.

It was found that 98 per cent farmers cultivating makhana are having less than 2 acres of the land.

\section{Leased pond}

The area of land taken on lease by farmer are categories in five groups which are up to 2 hectares, 2 to 4 hectare, 4 to 6 hectares, 6 to 8 hectares and above 8 hectare. In the table 8 , it was observed that the farmers taken pond on lease of up to 2 hectares were 41 in number which is 82 per cent, the famers taken pond on lease of 2 to 4 hectares were 8 in number which is 16 per cent, the farmers taken lease of more than 8 hectares of pond was only 1 in number which is 2 per cent.

It was found that 98 percent of the farmers has taken less than 4 hectares of pond on lease for cultivation of makhana. It was found in the survey that farmers take pond on lease thorough Fisherman Cooperative Society, which is working on block level.

In conclusion, Makhana is a unique crop which is cultivated only in a few districts in the country. It is a crop which requires highly skilled people for cultivation. Makhana 
growing farmers are usually illiterate, old aged and have large family size. The large family size provides them with a source of human labour. The makhana growers are having less owned land and they cultivate makhana on leased ponds. A large group of makhana growers are having income less than rupees one lakh. Majority of makhana grower are involved in other professions for their livelihood. Makhana cultivation highly labour intensive and involves high levels of human drudgery.

\section{References}

Chaitanya, A., 2011. GI portfolio analysis for enhancing income of makhana growers in Bihar, Project report PGDM, NAARM.

ICAR, 2003. Makhana report. 3-21.

Jain. A., Singh, H.B., Kanjlal, P.B., 2010. Economics of fox nut (Euryale ferox Salisb.) cultivation: A case study from Manipur in North Eastern India. Indian Journal of Natural Products and Resources. 1: 63-67.
Jha, S.N. and Prasad, S., 1996. Gorgon fruit or makhana- lts cultivation and processing. Indian Horticulture. 39(2): $18-20$

Kumar, A. 2018. A diagnostic study of makhana production technology among the growers of madhubani district of Bihar. Dr. RPCAU, M.Sc. Ag. (Extension Education) Thesis.

Mahawar, H.K., 2016. A report on Makhana (Fox nut) production, processing and supply chain. IIT, Mumbai. Technical Report available at (http://www.researchgate.net/publicatio n/318960974, 3-27.

Mandal, R.N., Saha, G.S. and Sarang, N., 2010. Harvesting and processing of makhana (Euryale ferox Salisb.)- An unique assemblage of traditional knowledge. Indian Journal of Traditional Knowledge. 9: 684-688.

Masram, P., Patel, K.S., Kori. V.K. and Rajgopala, S., 2016. Makhana (Eryale ferox Salisb)- A Review. Int. J. Ayu. Pharma. Chem. 4(2): 69-76.

\section{How to cite this article:}

Ansar Ahmad1 and Birendra Kumar. 2020. A Study on Socio-economic Condition of Farmers Cultivating Makhana in Darbhanga District of Bihar, India. Int.J.Curr.Microbiol.App.Sci. 9(02): 1318-1325. doi: https://doi.org/10.20546/ijcmas.2020.902.155 